\section{A Story-Based Analysis of Elementary Fourth Graders' Views on Respecting Differences}

\author{
Ömür Gürdoğan-Bayır*
}

\begin{tabular}{ll}
\hline Received: & 30 January 2019 \\
Revised: $\quad$ & 1 March 2019 \\
Accepted: & 14 March 2019 \\
ISSN: 1307-9298 \\
Copyright @ IEJEE \\
www.iejee.com
\end{tabular}

DOI: 10.26822/iejee.2019450798

\begin{abstract}
Respecting differences involves showing respect to individuals just because they are human beings and seeing every difference as natural. It is among the values that children need to acquire at early ages. Thus, there has been a need to reveal students' views on this value. The primary aim of this study was to examine elementary school students' views on respecting differences. Qualitative research method was employed in the study, and the participants were elementary fourth graders. The data were gathered through a story formed by the researcher, and questions related to it in moral, intellectual and empathetic dimensions. The students were also asked to create a poster about respecting differences. Descriptive analysis was used in the analysis of the students' answers, and content analysis was performed to examine their posters. The results showed that the students answered the questions in the moral dimension in a way that reflected their developmental characteristics. In addition, they perceived respecting differences mostly in the context of physical differences. In the empathetic dimension, the students stated how they would feel in the sample case provided. In their posters, they did not address universal values to a great extent. In this respect, sources such as current issues, sample cases and problems can be used in instructional processes to develop multiple perspectives regarding this value.
\end{abstract}

Keywords: Values, Respect, Respecting Differences, Morality, Intellectuality, Empathy

\section{Introduction}

Values can be defined as the principles that direct the lives of individuals. They act based on their values in situations when interpreting events, analysing what has happened and making decisions. The values that individuals have are also crucial for the continuity of the society they live in.

Values can be considered as the state of exhibiting terminal behaviours that overlap with the customs and traditions of the society (Ulusoy, 2017). Values constitute behavioural patterns due to including principals and beliefs that generally guide behaviours. For this reason, values have the characteristics of integration and organisation (Halstead \& Taylor, 2000). In other words, "values as desirable transsituational goals, varying in importance, that serve as guiding principles in the life of a person or other social entity" (Schwartz, 1994, p. 21). Values are not innate or inherited traits but are acquired in the course of life. As they live, individuals gain the values that would determine their personality, perspective and behaviours. Therefore, individuals' realising the values and adopting them are closely related to an educational process that is referred to as values education (Yeşil \& Aydın, 2007).

Values education is an important process that ensures the continuity of societies by enabling individuals' internalisation of values. By means of values education, individuals are able to transfer their culture to future generations. Considering that another crucial function of schools is cultural transfer, the importance of values education becomes even more obvious. In this respect, the Turkish Ministry of National Education (MoNE) (2018) indicates that values are a collection of principles that form the perspective of educational curricula. Accordingly, the values of justice, friendship, honesty, self-control, respect, love, responsibility, patriotism and helpfulness are included in the curricula as basic values.
Respect, which is one of these basic values included in the curricula, refers to a set of values that affect every area of life and are needed in human relationships (Öksüz \& Güven, 2012). It can be defined as the feeling of importance and value in individuals. In fact, respect is one's original identity (YIlmaz, 2016). The value of respect can be addressed in different dimensions as in respecting differences, the cultural heritage and the elderly.

Respecting differences involves showing respect to individuals just because they are human beings and seeing every difference as natural. In this sense, it can be claimed that this value establish peace among people and teach individuals to protect each other's rights (Capowski, 1996: cited in Topçubaşı, 2015). Differences essentially exist in human nature. Elements such as age, gender, race, ethnic origin, language and religion that distinguish people from each other can be defined as differences (Atasoy, 2012).

Considering that individuals are subjective entities, it is accepted as natural whether they adopt or appreciate certain difference or not. However, the respect that individuals show to differences prevents conflicts that would not be solved otherwise. This is because individuals should be respected as it is a basic need that should be met for developing a healthy personality. While they more easily show respect to traits such as race and colour that cannot be changed, they expect differences in views or beliefs to be changed (Öksüz \& Güven, 2012). A peaceful society can be created if respecting differences is taught starting from childhood. People percept differences as strength of the society via the value of respecting differences.

Respecting differences, help children adopt a positive attitude towards differences, understand other who have different characteristics and form new opinions about them (Hall, 1999: cited in Ekmişoğlu, 2007). With regard to the education 
that involves respecting differences, the Foundation for the Support of Women's Work - FSWW - (2006) highlights noticing prejudices and trying to eliminate them, showing respect to differences by understanding the behaviours of others and attempting to sympathise with them. This is because respecting differences should be adopted in order for different cultures to live happily together (Kanatlı-Öztürk, 2018). Sources such as sample cases and current issues can be employed for teaching in introducing this value to students, and having them to acquire affective characteristics like empathy, tolerance and accepting others as they are (Deveci \& Çengelci-Köse, 2016). In this context, it can be argued that respecting differences is an issue that should be attached great importance for social continuity and peace.

In the national literature on respecting differences, there are studies that received the views of preschool teachers on this value (Pekdoğan, 2018; Ekmişoğlu, 2007) and those that attempted to teach it by means of different curricula (Çatlak \& Yiğit, 2017; Eren, 2015; Kanatlı-Öztürk, 2018; Topçubaşı, 2015). In the international literature on respecting differences were associated with multiculturalism and antibias education (Derman-Sparks, 1989; Oslon, 2003; Garmon, 2004; Endres, 2002; Weisman \& Garza, 2002). It seems that the existing research mostly focused on developing the value of respecting differences and was conducted at the preschool level. Yet, no studies have been published which set out to reveal elementary school students' views on respecting differences based on a story. Therefore, this study focuses on perspective of primary school students on respecting differences with moral, empathic and intellectual questions. Findings of the study which include answers of students in moral, empathic and intellectual dimensions will be discussed considering development level of students.

Thus, this study is significant in terms of revealing students' perceptions of respect for differences and promoting teaching value of respecting differences. In this sense, this study aimed at examining elementary fourth graders' views on respecting differences by making use of a story. The following research questions were thus addressed in the study:

- What are elementary fourth graders' views on respecting differences

in terms of the moral dimension?

in terms of the intellectual dimension?

in terms of the empathetic dimension?

- How do elementary fourth graders' express their views in their drawings about respecting differences?

\section{Method}

\section{Research Model}

This study is a descriptive attempt to reveal elementary fourth graders' views on respecting differences. Interpretive design, an umbrella term in qualitative research, was adopted in the study in which qualitative data were collected. How individuals interpret their experiences, the meanings they attribute to such experiences and how they construct them are addressed in this kind of studies (Merriam, 2002). Accordingly, how fourth graders perceived the concept of respecting differences was examined in the present study by means of a story created for research purposes.

\section{Participants}

The participants of the study were fourth-grade elementary school students. Convenient sampling was used in the selection of the participants. In this type of sampling, an imme- diate and easy-to-reach case is chosen (Yıldırım \& Şimşek, 2013). A total of 98 elementary fourth graders participated in this study. Fifty-one of these students were female and 47 were male.

\section{Data Collection}

The data were collected through an instrument developed by the researcher. This instrument included a story about respecting differences that was prepared by the researcher, and moral, intellectual and empathetic questions related to the story. In addition, the students were asked to reflect the value of respecting differences by drawing a poster on the issue and writing down what they expressed in the poster. In this scope, the instrument contained a story about respecting differences, and a total of 11 items including 10 questions related to the story and a task asking students to create a poster. After it was developed, the instrument was presented to a group of six experts including two in social studies education, one in educational curricula and instruction and three in elementary education, for their feedback. Three elementary school teachers and three fourth-grade students also provided opinions. Based on the feedback received, the instrument was finalised for administration.

The first part of the instrument included the story written by the researcher and the related questions. This is because stories can present a social event/issue to students in the form of opposite views or perspectives like good/bad or right/wrong. Besides, stories enable students to see the contrasts, conflicts and differences within life (Kabapınar \& Baysal, 2004). In this way, the students were encouraged to reveal their perspectives of respecting differences by means of a story.

The students were asked questions in moral, intellectual and empathetic dimensions with regard to the story. Rowe and Newton (1994) assert that moral, intellectual and empathetic categories of analysis should be employed in story analysis. Therefore, the instrument contained moral questions on whether the characters in the story did right or wrong, intellectual questions on the characters' justifications for certain behaviours and empathetic questions in which the student put themselves in the shoes of the characters (Kabapınar \& Baysal, 2004). Thus, the students were enabled to reflect the value of respecting differences in cognitive and affective dimensions.

The data gathering instrument also included a task by which the students were asked to prepare a poster regarding the value of respecting differences and explain what they wanted to express in their posters. Revealing children's perceptions through pictures is a reflective approach in terms of understanding their inner worlds (Belet \& Türkkan, 2007). In this way, the students' perceptions of respecting differences were also demonstrated through posters.

The data were gathered by the researcher herself, and she gathered the data in two class hours. After the copies of the instrument were distributed to the students, any questions that they had about the items were answered. The instrument employed in the study is as follows:

"A cheerful black rabbit with one ear missing lives in a jungle. As she wanders around the jungle all alone, she comes across a squirrel. She offers the squirrel if they can be friends. Because she believes that if they played together, they would have a good time. But the squirrel turns down the rabbit and makes fun of her by saying "You don't have your other ear, and your colour is different from mine". The rabbit gets really upset and starts thinking how she could be friends with the squirrel. She thinks about changing her colour with paint and making an ear for herself with hard leaves in the jungle. But then she decides that all these are not right. One day, while walking around the jungle, the squirrel gets a thorn on his foot. It is very painful. He comes to his friends. When they see that he can't walk and 
run properly, they don't accept him to their play. The squirrel gets really upset and remembers what he said to the rabbit. He then looks for the rabbit in the jungle and finds her. He apologises from her and says they can be friends if she wants. The rabbit feels quite happy with the squirrel's apology and offer. She says she can help him walk and share her food with him. After that day, the rabbit and the squirrel become good friends, and all the other animals in the jungle show them as the example of friendship."

1. Do you think the squirrel's teasing the rabbit by saying "You don't have your other ear, and your colour is different from mine" is right? Why?

2. Do you think the squirrel's friends not accepting him to their play is right or wrong? Why?

3. Do you think the rabbit's forgiving the squirrel and helping him is right or wrong? Why?

4. What are individual differences?

5. What do you think respecting differences is?

6. What does the saying "Differences are the spice of life" mean?

7. What do you think the best title for this story would be? Why?

8. If you were the squirrel, what would you do in the face of the rabbit's offer for friendship? Why?

9. When you put yourself in the rabbit's shoes, how would you feel with the squirrel's teasing?

10. If you were the squirrel to whom the rabbit helps, how would you feel? Why?

11. Prepare a poster about respecting differences in the space below. (Write down what you want to express on the back side of the paper.

\section{Data Analysis}

The descriptive analysis technique was employed in the study to analyse the answers provided for the questions related to the story. In accordance with descriptive analysis, data are summarised based on pre-set themes (Yıldırım \& Şimşek, 2013). In the present study, the data were analysed in the context of the questions included in the instrument.

Content analysis was used in the analysis of the data regarding the posters. In this analysis, it is aimed to reach the relationships that can provide further explanations for the data (Yıldırım \& Şimşek, 2013). In this regard, themes were formed based on the students' posters and what they wanted to express in their posters.

The research data were independently analysed by the researcher and another field expert in social studies education. Later in the process, the researcher and the outside researcher discussed the points in which they had agreements or disagreements, and accordingly the analysis was completed. Lastly, specific codes (i.e. S1, S2, etc.) were used in the presentation of the findings while providing direct quotations.

\section{Findings}

In the study, the findings were reported with respect to the research questions. The themes were presented in tables, and direct quotations from the students were provided.

\section{Findings Regarding the Moral Dimension}

In the framework of the sample case given in the study, the findings regarding the moral dimension are presented in Table 1.
Table 1. Findings regarding the moral dimension

\begin{tabular}{|c|c|}
\hline Teasing & $f$ \\
\hline Differences being natural & 20 \\
\hline A bad behaviour & 22 \\
\hline The possibility of experiencing the same & 5 \\
\hline Being compatible with others & 7 \\
\hline Hurting others & 10 \\
\hline Not being discriminatory & 10 \\
\hline Personality traits being more important & 7 \\
\hline \multicolumn{2}{|l|}{ Exclusion from the Play } \\
\hline Lack of empathy & 21 \\
\hline Togetherness & 11 \\
\hline The right to play & 24 \\
\hline Selecting games suitable for differences & 8 \\
\hline Punishment & 5 \\
\hline \multicolumn{2}{|l|}{ Being Helpful } \\
\hline Showing what is wrong & 9 \\
\hline Being good despite bad actions & 7 \\
\hline Not feeling resentment & 8 \\
\hline Apologising & 6 \\
\hline Learning a lesson & 18 \\
\hline Forgiving & 18 \\
\hline
\end{tabular}

As is seen in Table 1, the findings regarding the moral dimension were gathered under the themes of teasing, exclusion from the play and being helpful based on the questions included in the instrument. In this respect, for the question "Do you think the squirrel's teasing with the rabbit by saying 'You don't have your other ear, and your colour is different from mine' is right? Why?", which examines whether teasing is right or wrong based on the sample case, all of the students stated that this behaviour was wrong. The students' justifications for this answer included that differences were natural, teasing was a bad behaviour, they had the possibility of experiencing the same situation, individuals should be compatible with others, teasing would hurt others, one should not be discriminatory and personality traits were more important than physical characteristics. One of the students who thought that teasing was wrong because differences were natural said, "All living beings have different characteristics, even though they may look bad (S9)," while another student said, "Because everyone is different from each other. Our differences make us who we are (S33)." One student who thought teasing was a bad behaviour explained his argument by saying "Making fun of other people's physical traits is not a good behaviour (S18)." Another student explained her justification by asserting "The same thing can also happen to him (S32)." One of the students who thought personality traits were more important than physical characteristics emphasised one's character by saying "You should look at the beauty of one's heart, not his/her appearance (S18)." The students thus argued that teasing with one's differences was wrong, and differences were only natural.

As can be seen in the table, for the question "Do you think the squirrel's friends not accepting him to their play is right or wrong? Why?", which examines whether the behaviour of excluding one from the play due to differences was right or wrong, most of the students thought this behaviour was wrong. Their justifications included the lack of empathy, the importance of togetherness and that everybody had a right to play. Moreover, the students stated that games suitable for differences should be played. However, five of the students thought the exclusion from the play was right because the squirrel needed to be pun- 
ished for his previous behaviour against the rabbit. One of the students who argued that the exclusion was wrong said, "Because they should be kind to the squirrel about whether he can play or not, they should show some empathy (S6)" and thus highlighted the lack of empathy. Similarly, another student who pointed to the lack of empathy said, "Because they should show empathy and help him, accept him to their play (S86)." One student who expressed the importance of togetherness said, "Because nobody should be excluded, unity and togetherness are important (T27)." One of the students who thought that everybody had the right to play explained his view by saying, "Because everybody has the right to play. Instead of not accepting him to the play, they should have asked what happened to his foot (S46)." Another student interpreted this issue in terms of individual rights by saying, "Everyone has the right to play no matter what (S52)." One of the students who argued that situations suitable for differences should be considered, and said, "The squirrel should have played, too. For instance, if they were playing football, he could be the goalkeeper (S32)." A similar view was also stated by another student: "They could pick a game that he could play with that foot (S85)." One student who thought this behaviour was right said, "Because the squirrel did the same thing before, he deserved it (S41)," while another said, "He did it, too. He needed to get punished to understand his mistake (S64)." Consequently, most of the students were found to think that this behaviour, the exclusion of the squirrel from the play, was wrong in terms of the right to play.

As can be seen in the table, for the question "Do you think the rabbit's forgiving the squirrel and helping him is right or wrong? Why?", which examines the helpfulness in the sample case, all of the students thought helping out the squirrel was the right behaviour. The students justifications for their view included forgiveness, one's having learned a lesson, showing what is wrong, not feeling resentment, being good despite the bad and apologising. One of the students highlighted forgiveness by saying, "Everybody deserves another chance. We should forgive them (S27)", whereas another student featured one's having learned a lesson by asserting, "Because the squirrel learned his lesson as he understood what he had done was wrong (S28)." One student who thought that individuals who exhibit a wrong behaviour should be told so said, "We should correct our friend's mistake (S23)." One of the students who pointed out that there should be no resentment towards others said, "People get offended, and then make peace. It is important to make the peace afterwards. Nobody should resent another person (S46)." The students who explained their views by saying, "You don't respond to a bad action with another bad action (S6)," and "We should help them even if they did wrong to us (S10)" argued that individuals should behave kindly towards others even in the face of a bad action. Therefore, it can be argued that all of the students cared about helpfulness.

\section{Findings Regarding the Intellectual Dimension}

The findings with regard to the intellectual dimension are presented in Table 2.

As is seen in Table 2, the findings regarding the intellectual dimension were gathered under the themes of definition of individual differences, definition of respecting differences, differences being the spice of life and the title of the text based on the questions included in the instrument. The students defined individual differences as being unique to the individual, and physical characteristics, feelings and views and interests being different. Regarding this concept, most of the students made reference to physical characteristics. One of the students who defined individual differences as physical characteristics being different said, "It is about skin colour, height, eye colour and weight being different (S6)," including physical characteristics in her definition. Another student said, "For instance, my eyes are black, yours are green (S24)" giving an example about the colour of eyes. One student who highlighted the difference in interests said, "One person likes football, another person likes volleyball, another likes playing the piano." One of the students who regarded uniqueness as an indicator of individual difference asserted, "These are the characteristics that change for every individual (S16)." Another student who defined the concept as "the change in an individual's feelings like respect, compassion, kindness (S77)" explaining the differences in feelings with examples of values. As a result, the students explained individual differences mostly with examples related to physical characteristics.

Table 2. Findings regarding the intellectual dimension

\begin{tabular}{cc}
\hline Definition of Individual Differences & $f$ \\
\hline Being unique to the individual & 16 \\
\hline Physical characteristics & 39 \\
\hline Feelings and views & 10 \\
\hline Interests & 24 \\
\hline Definition of Respecting Differences & 25 \\
\hline Tolerance & 6 \\
\hline Empathy & 5 \\
\hline Accepting individuals as they are & 16 \\
\hline Not teasing others & 5 \\
\hline Not being discriminatory & 3 \\
\hline Making friends \\
\hline Differences are the Spices of Life & 12 \\
\hline Being open to novelties & 11 \\
\hline Having distinguishing characteristics & 52 \\
\hline Making life more beautiful/less boring \\
\hline The rabbit and the squirrel \\
\hline Our differences/Respect to differences \\
\hline Friendship \\
\hline Discrimination \\
\hline Helping each other \\
\hline What goes around comes around \\
\hline Different but happy \\
\hline Text need is a friend indeed \\
\hline
\end{tabular}

As is seen in the table, the students explained the value of respecting differences with tolerance, empathy, accepting individuals as they are, not teasing others, not being discriminatory and making friends. One of the students who defined respecting differences in relation to tolerance said, "It is about approaching others with tolerance, showing them tolerance (S5)." Another student said, "It is about not teasing others because of their differences (S17)" mentioning what behaviour would be wrong. One of the students who defined respecting differences as "showing empathy (S60)" highlighted empathy, while one student emphasised unconditional acceptance by saying, "It is about seeing individuals as they are (S6)", and another student provided an example about disability while explaining discrimination by saying, "For instance, if we have a friend with disability, we should also include him in the play, not exclude him (S22)." All in all, the students were observed to relate respecting differences with tolerance the most.

In the intellectual dimension, the students were asked what the saying "Differences are the spice of life" meant? Most of the students answer this question by saying that differences made life more beautiful and less boring. Furthermore, some of the students associated this saying with being open 
to novelties and difference distinguishing people from each other. One of the students who thought that differences made life less boring said, "Life would be very boring if everyone was the same (S17)", another said "Our life becomes more beautiful with differences (S19)." Another student thought that differences led to the emergence of new ideas by saying "Differences open the way for novelties. Without differences, everybody would think the same way and nothing new would be invented (S27)." One student also stated that differences were the distinguishing features of individuals and thus made reference to physical differences by saying, "If everybody had the same look, nobody would be able to recognise each other, that's why it is good that everybody is different (S38)." In this regard, the students perceived differences as making life better

In the intellectual dimension, the students were also asked to find a title for the story. Most of the students thought the title "Our Differences/Respecting Differences" would be suitable, directly addressing the text and the questions. Moreover, some of the students wrote titles such as "the rabbit and the squirrel", "Friendship", "Discrimination", "Helpfulness", and "Different but Happy". Additionally, there were students who made use of proverbs including "What comes around goes around" and "A friend in need is a friend indeed".

\section{Findings Regarding the Empathetic Dimension}

The findings with regard to the empathetic dimension are presented in Table 3.

Table 3. Findings regarding the empathetic dimension

\begin{tabular}{|c|c|}
\hline Offer to Become Friends & $f$ \\
\hline Considering personality traits & 28 \\
\hline Showing respect & 13 \\
\hline Making friends & 51 \\
\hline \multicolumn{2}{|l|}{ Teasing } \\
\hline Getting upset & 85 \\
\hline Resentment & 3 \\
\hline Getting angry & 7 \\
\hline Not caring & 1 \\
\hline \multicolumn{2}{|l|}{ Being Helpful } \\
\hline Feeling happy & 43 \\
\hline Feeling ashamed & 19 \\
\hline Feeling angry & 2 \\
\hline Feeling regretful & 18 \\
\hline
\end{tabular}

As is seen in Table 3, for the question "If you were the squirrel, what would you do in the face of the rabbit's offer for friendship? Why?", the students stated that they would accept this offer. The students accepted the offer due to reasons such as considering personality traits, showing respect and making a new friend. One of the students who thought that personality traits were more important than physical characteristics said, "Because we should look at living beings' personality traits, perhaps he is a good person. I mean we should decide based on personality traits (S81)." Another student who emphasised the respect to differences said, "I would accept it because we should be respectful to differences (S23)." The student that put to the forefront the idea of making a new friend said, "Because I would have another friend (S19)." A similar view was also stated by another student: "I like to meet new people (S10)." It seems that the students cared about making friends and getting to know new people.

For the question "When you put yourself in the rabbit's shoes, how would you feel with the squirrel's teasing?", which is under the empathetic dimension and examines how they would feel if they were the rabbit, most of the students said they would feel upset. Some of the students explained their feelings with resentment, anger and indifference. One of the students who stated that he would be hurt in such a situation said, "I would get upset. Because what he said would hurt my heart (S5)." Another student said, "I would get hurt and resent the squirrel. I wouldn't speak with him again (S44)," indicating that she would show resentment to that behaviour. One student who reported to react to such a situation with anger said, "I would get angry. Because he can't make fun of me (S92)." Another student stated that he would not care about being rejected said, "I would just turn my back and leave. I wouldn't even care (S97)." It can thus be argued that the students were aware teasing is a behaviour that upsets others.

For the question "If you were the squirrel to whom the rabbit helps, how would you feel? Why?", which is under the empathetic dimension, most of the students wrote that they would feel happy. Some of the students, though, stated that they would feel ashamed and regretful, and get angry at themselves. One of the students said, "I would be happy because I would have a good friend (S22)," while another student emphasised shame by saying, "I would be ashamed of my past actions (S3)." The student who questioned the behaviour and featured regret said, "I would feel regret. Because what the squirrel did was not right at all (S6).", whereas another student who mentioned anger said, "I would get really angry at myself, because I made fun of her and then she helped me out (S5)."

\section{Findings Obtained from the Posters}

The findings with regard to the posters created by the students are presented in Table 4.

Table 4. Findings obtained from the posters

\begin{tabular}{|c|c|}
\hline Posters & $f$ \\
\hline Helping each other & 10 \\
\hline Peace & 2 \\
\hline Equality & 6 \\
\hline Happiness & 14 \\
\hline Friendship & 29 \\
\hline Not teasing others & 18 \\
\hline
\end{tabular}

As can be seen in Table 4, the students highlighted friendship, the wrongness of teasing, helping each other, happiness, equality and peace. In other words, they explained respecting differences by featuring these aspects. The students' posters that covered friendship are presented in Pictures 1 and 2.

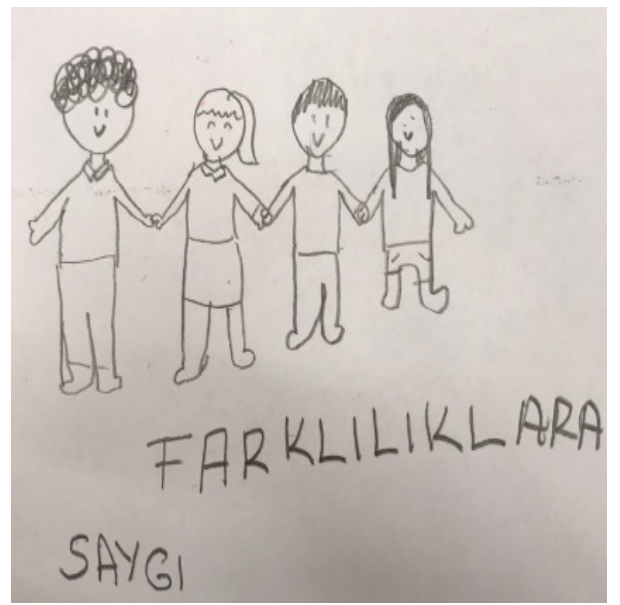


Picture 1. S27's poster on friendship

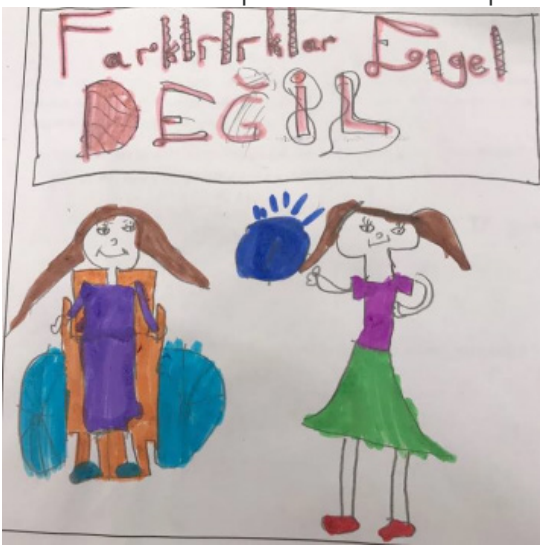

Picture 2. S34's poster on friendship

S27 made children holding hands in her poster, and regarding why she drew this poster on respecting differences she said, "We should be respectful to differences. Nobody should be judged just because they are different. Different people can become friends with each other. That is what I expressed in my poster." On the other hand, S34 drew two children, one with and the other without disability. About her poster she said, "One of the kids has a disability, and the other doesn't. They have become friends and can play together without any problems." referring to physical disabilities. One student's poster that associated respecting differences with happiness is shown in Picture 3, and that of another student about peace in Picture 4.

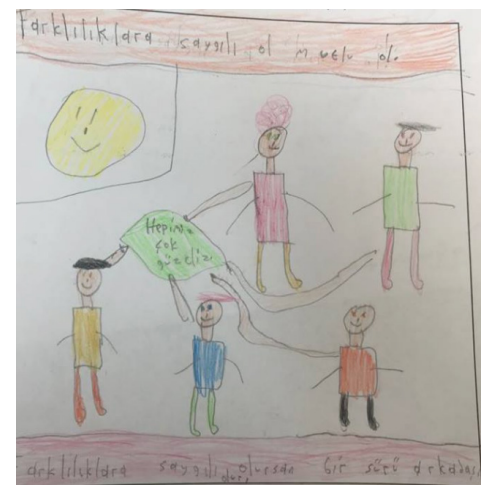

Picture 3. S87's poster (happiness)

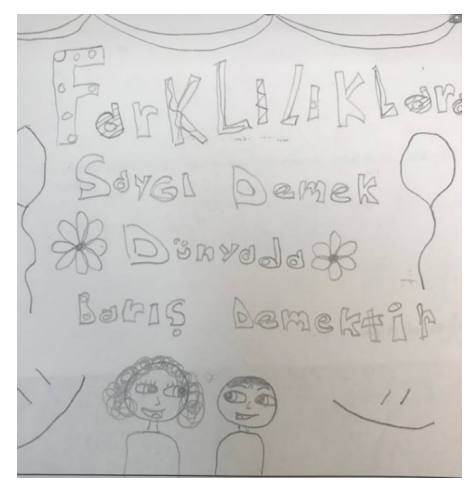

Picture 4. S92's poster (peace)

S87 drew individuals with different characteristics and wrote down slogans. He explained why he drew that poster by saying, "There are people around us who have different characteristics. We live in a peaceful world only when we respect them." putting happiness to the forefront. S92 included a slogan in her poster and drew individuals with different gender. For her poster, she said, "When differences are respected, everybody feels normal and peace is ensured in the world." S1's poster that focused on helpfulness and S77's poster about equality are presented in Pictures 5 and 6 , respectively.

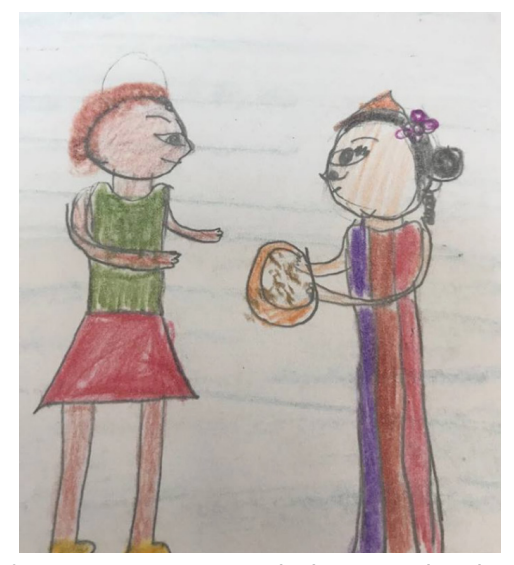

Picture 5. S1's poster (helping each other)

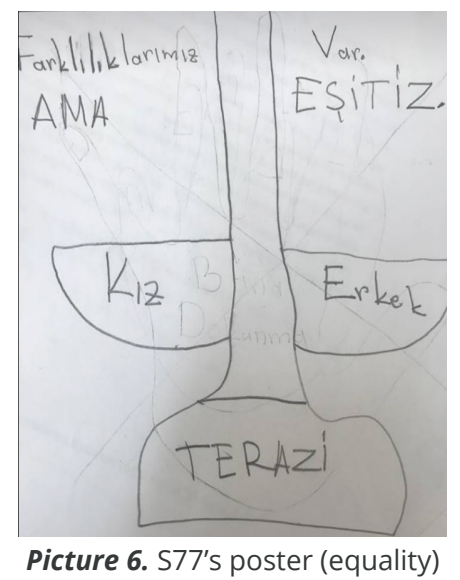

As can be seen, $\mathrm{S} 1$ drew a poster about individuals' helping each other and explained it by saying, "The reason why I drew this poster is that people should help and respect each other even though they may be different." S77 who included a scale and individuals of different genders in his poster emphasised equality with regard to respecting differences. He explained his poster by saying, "Girl or boy, we are all equal, that's what I wanted to express." S24's poster on teasing is shown in Picture 7 below.

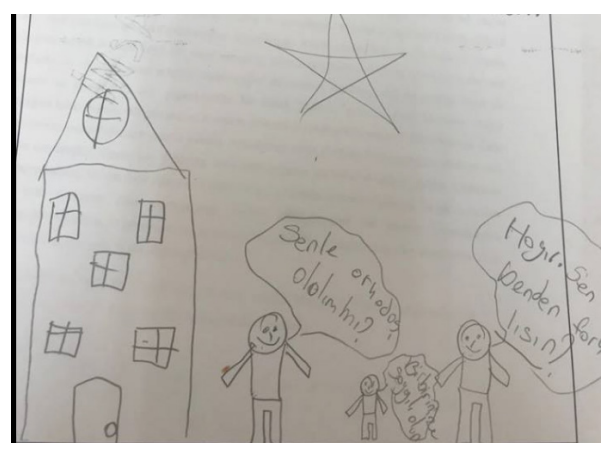

Picture 7. S24's poster on teasing

In his poster, S24 included expressions related to differences in speech bubbles. He said, "We should not make fun of individuals' differences, but respect them," to explain why he included those in his poster. Consequently, the students attempted to explain respecting differences mostly with values such as helpfulness, peace, equality and friendship. 


\section{Results, Discussion and Suggesiton}

In the present study, elementary school students' views on respecting differences were examined by means of a sample case. The students were asked questions in the moral, intellectual and empathetic dimensions, and the value of respecting differences was addressed from multiple perspectives. In addition, they were asked to create a poster on this issue to show how they reflected their perceptions in visuals.

In the moral dimension related to the sample case presented to the students, they were asked to state whether certain behaviours were right or wrong. The students answered the question about teasing by stating that it was the wrong behaviour. They also asserted that people should not be discriminatory, others can be offended, one should be compatible with them and anybody can experience similar situations. They evaluated similar cases they encountered with moral judgements. A moral judgement is defined as a mental process by which a decision is made about whether a behaviour is right or wrong, and how one and others should behave in the face of such a situation (Çileli, 1995). Moral judgements are related to the mora developmental period of children, in which age is a significant factor (Cesur \& Topçu, 2010). Therefore, the students answers should be discussed with reference to the age-related period in moral development theories. According to Piaget's and Kohlberg's moral development theories, the period that complies with the students' age is a period in which social and external rules are important. In other words, children of this period act based on moral norms set by the society (Söylemez, 2017). For this reason, the fact that the students' views regarding inaccuracy of teasing could be explained in terms of social rules. It is possible that the students provided this answer because teasing is regarded as a bad behaviour in the society. Some of the students stated that one should not tease others in such a situation but should be compatible with them because they could be hurt and the same thing could happen to anybody. It can be said that the students are at the traditional level based on Kohlberg's theory. This is because in this level that corresponds to one level higher than social roles, it is important to exhibit good behaviours, make others happy and help them out (Senemoğlu, 2012). In a similar vein, the behaviour of exclusion from the play in the moral dimension was regarded as wrong by the students. Some of these students pointed to the lack of empathy, and thus they again seem to be at the traditional level in which looking from others' points of views is seen important according to Kohlberg (Senemoğlu, 2012) On the other hand, some students responded to this question by referring to the children's right regarding play. In the literature, results of the studies conducted with children, show that the right to play is accepted as one of the children's right by them (Gültekin, Gürdoğan-Bayır, \& Balbağ 2016; Ersoy, 2011; Covell \& Howe, 1999). Thus, it is quite normal that the students saw it as a right and thought the exclusion from the play was wrong. Additionally, learning outcomes included in the curricula regarding children's rights may help children develop awareness about right of the play. Besides, only few students thought this exclusion was right because the squirrel deserved a punishment. In another question on helpfulness in the moral dimension, students evaluated being helpful as the right behaviour due to reasons such as forgiveness and one's having learned a lesson. The fact that the students featured punishment in the exclusion, and learning a lesson in helpfulness can be associated with the level of obedience and punishment prior to the traditional level (Senemoğlu, 2012) In addition, punishment is included among the factors that affect moral and immoral behaviours in Gander and Gardiner's (1998) social learning theory (Sözer-Çapan, 2005). Furthermore, in a study at preschool level, Meriç and Özyürek (2018) reported that moral rules required more punishment according to the children, which is consistent with the findings regarding punishment in the present study. Considering the results on the moral dimension, it seems that the students provided different answers depending on the questions. In other words, while they took social rules into consideration in one occasion, they highlighted caring about others in another. In another study, Lickona (1976) revealed that children sometimes provided outside-dependent and sometime independent answers (Sözer-Çapan, 2005). As a result, it can be argued that the students' judgements in the moral dimension reflected the characteristics of their developmental period.

In the study, the students were asked to define individual differences and respecting differences in the intellectual dimension. Most of the students mentioned physical characteristics like height, weight and eye colour while defining individual differences. Thus, it can be said that they mostly focused on observable traits as a difference. Considering their age, they were in the concrete operations period, and they seem to reflect the characteristics of this cognitive developmental period. The students thought of mainly the differences that cannot be changes as an individual difference. The study conducted with elementary school students, Öksüz et al. (2015) reported that the students' drawings on differences included a wider coverage of the differences related to one's appearance. As for the definition of respecting differences, he students mostly highlighted the value of tolerance. Yet, in a study at elementary school level, very few students associated tolerance with respecting differences (Ersoy, 2016) although tolerance is mainly explained with accepting differences, understanding and respect in the literature (Karaman-Kepenekçi, 2004; Witenberg, 2007). Therefore, the results of the current study are supported by the literature. The students also mentioned the ability to show empathy in their definitions of respecting differences. Looking at a situation from another person's perspective brings respect to differences and a democratic attitude (Kabapınar, 2004). Besides, in their study, Uymaz and Çalışkan (2018) formed the theme of respecting differences with regard to the metaphors about empathy. In this sense, the finding that the students mentioned empathy in the context of respecting difference overlaps with the literature. In the intellectual dimension, the students were also asked to explain the saying "Differences are the spice of life". Regarding this saying, they stated that differences made life more beautiful and less boring, enabled individuals to be open to novelties, and distinguished them from each other. As seen in the direct quotations the students did not use a variety of words to explain the saying. Similarly, Çıplak (2005) reported that students produced less variety of words while explaining proverbs. It can thus be argued that children of this age group do not make use of a variety of words to explain expressions such as proverbs, idioms and sayings. Lastly, in the intellectual dimension, the students were asked to find a title for the story. Most of the students wrote titles including "Our Differences/ Respecting Differences" and "The Rabbit and the Squirrel" that were directly related to the text content. Only few students found interesting titles. In a similar vein, Başaran (2014) reported that students had difficulty in finding interesting text titles but could easily find titles that reflected the text content. Based on the questions in the intellectual dimension, the students can be said to define respecting difference in parallel with the literature.

In the study, the students were asked what they would do and how they would feel in the situations narrated in the story. They said they would accept the friendship offer because they would make a new friend. According to Maslow's hierarchy of needs, when individuals meet their physiological and security needs, they want to meet their 
need to be part of a group like family or friends. In this regard, it seems normal that most of the students responded to this question as indicating their willingness to make friends. Moreover, the age of the students who participated in the study corresponds to the latency period in Freud's theory of psychosexual development, and to the industry versus inferiority period in Erikson's theory of psychosocial development. In these theories, it is indicated that children of this age group attach more importance to friendship (Senemoğlu, 2012). In the empathetic dimension, the students were asked how they would feel if they were the one who is teased, based on the sample case in the story. Teasing is among the reasons behind conflicts in children of this age group (Gürdoğan-Bayır \& Gültekin, 2016). One of the reasons behind children's behaviour of teasing is not being able to understand differences (Topaloğlu, 2014). In this study, the students said they would get upset and angry in such a situation. However, children's reaction of getting upset and angry would cause the continuity of teasing (Alantar, 2010 cited in Gür, 2011). In this context, the students participated in the present study could understand the feelings of an individual who is teased but did not know how to cope with it. It may be caused from emphasizing cognitive behaviour in the teaching process more than affective education. The students were also asked how they would feel if someone else helped them, and they mostly said they would be happy. Helpfulness can be regarded as a morally good behaviour, and such behaviours would make the individual and others feel happy (Montagu, 1964 cited in Akbaş, 2008). Thus, it can be expected that the students would also feel happy. Accordingly, the students were able put themselves in the shoes of another person with regard to the empathetic dimension.

In the study, the students were asked to create a poster about respecting differences. They addressed friendship, happiness, helpfulness, teasing, peace and equality in their posters. The finding that they mostly featured the value of friendship can be related to their social development. Moreover, the students explained respecting differences in their posters mostly with positive situations. In Öksüz et al. (2015), students similarly included categories reflecting positive attitudes in their drawings about respecting differences. In the present study, peace was the value included the least in the students' posters. In fact, peace involves respecting differences, tolerance, helpfulness, friendship, love and solidarity (Çoşkun \& Keskin-Keskin, 2009; Cengelci-Kose \& Gurdogan Bayir, 2016). It can then be argued that the students perceived respecting differences in the context of friendship and made less reference to other universal values such as peace, equality and justice while explaining it.

As a result, the students responded to the moral, intellectual and empathetic questions related to the sample case by reflecting the characteristics of their developmental period. In the intellectual dimension, they highlighted physical characteristics for the value of respecting differences but did not mention differences in feelings and views However, putting into consideration such differences in ensuring social peace would enable conflicts to be solved peacefully. Besides, considering that respecting differences is important in all societies, it would be beneficial to deepen students' perspectives. In this respect, sources such as current issues, sample cases and problems can be used in the instructional process to develop multiple perspectives regarding this value. This is because these sources would enable students to become more sensitive to social issues. Additionally, issues that focus on differences in feelings and views can be covered in classes. In the literature, the research on respecting differences is mostly quantitative, and thus in-depth qualitative studies can be conducted to examine this value. Longitudinal studies can also be carried out to observe students' longterm development.

\section{References}

Akbaş, O. (2008). Değer eğitimi akımlarına genel bir bakış. Değerler Eğitimi Dergisi, 6(16), 9-27.

Başaran, M. (2014). 4. sınıf öğrencilerinin metne başlık bulma becerilerinin incelenmesi, 13. Ulusal Sını Öğretmenliği Sempozyumu, Dumlupınar Üniversitesi Eğitim Fakültesi, Kütahya.

Belet, Ş. D., \& Türkkan, B. (2007). ilköğretim öğrencilerinin yazılı anlatım ve resimsel ifadelerinde algı ve gözlemlerini ifade biçimleri (Avrupa Birliği örneği). VI. Ulusal Sınıf Öğretmenliği Eğitimi Sempozyumu, 270-278.

Cengelci Kose, T. \& Gurdogan Bayir, O. (2016). Perception of peace in students' drawings. Eurasian Journal of Educational Research, 65, 181-198.

Cesur, S., \& Topçu, M. S. (2010). Değerlerin belirlenmesi testinin güvenirlik ve geçerlik çalışması ve yaş, eğitim, cinsiyet ve ebeveyn eğitiminin ahlaki gelişim ile ilişkisi. Elektronik Sosyal Bilimler Dergisi, 19, 106-125.

Covell, K. ve Howe, R. B. (1999). The impact of children's rights education: a Canadian study. The International journal of Children's Rights, 7, 171-183.

Çatlak, I. H., Yiğit, E. Ö. (2017). Sosyal bilgiler öğretmen adaylarına empati becerisi ve farklılıklara saygılı olma değerinin kazandırılmasında storyline yönteminin etkisi. Abant İzzet Baysal Üniversitesi Eğitim Fakültesi Dergisi, 17(4), 1794-1819.

Çıplak, M. (2005). Uşak merkez ilköğretim 5., 8. ve 11. sınıfların yazılı kelime hazinesinin belirlenmesi (Unpublished MA Thesis) Afyon Kocatepe Üniversitesi, Sosyal Bilimler Enstitüsü.

Çileli, M. (1995). Ahlak psikolojisi ve eğitim. Ankara: Verso Yayınları.

Derman-Sparks, L. and A.B.C Task Force; (1989) Anti-bias curriculum: tools for empowering young children, Washington.

Deveci, H. \& Çengelci-Köse, T. (2016). Değer eğitiminde güncel olaylar ile belirli gün ve haftalardan yararlanma. R. Turan \& K. Ulusoy (Eds.) Farklı yönleriyle değer eğitimi içinde. Ankara: Pegem Akademi.

Ekmişoğlu, M. (2007). Erken çocukluk döneminde farklılıklara saygı kavramı hakkında öğretmen görüşlerinin incelenmesi ve farklılıklara saygı ölçeği'nin geçerlik ve güvenirlik çalıșması (Unpublished MA Thesis). Çanakkale On Sekiz Mart Üniversitesi: Çanakkale.

Endres, B. (2002). Transcending and attending to difference in the multicultural classroom. Journal of Philosophy of Education, 36(2), 171-185.

Eren, S. (2015). Öyküleştirme yöntemine dayalı eğitimin beş yaş çocuklarında farklılıklara saygı kazanımına etkisinin incelenmesi (Unpublished MA Thesis). Hacettepe Üniversitesi: Ankara.

Ersoy, A. F. (2011). İlköğretim öğrencilerinin çocuk haklarına ilişkin algıları. ilköğretim Online, 10(1): 20-39.

Ersoy, A. F. (2016). Dördüncü sınıf öğrencilerinin hoşgörü algısı ve deneyimleri: Bir fenomenolojik araştırma. Mersin Üniversitesi Eğitim Fakültesi Dergisi, 12(1): 454473.

Garmon, M. A. (2004). Changing preservice teachers-attitudes/beliefs about diversity what are the critical factors. Journal of Teacher Education, 55(3), 201-2013. 
Gültekin, M., Gürdoğan-Bayır, Ö., \& Balbağ, N. L. (2016). Haklarımız var çocukların gözünden çocuk hakları. Adıyaman Üniversitesi Sosyal Bilimler Dergisi, 8(24), 945-970.

Gür, Ç. (2011). Üstün yetenekli çocukların karşılaştığı sosyal ve duygusal problemler ve bu problemlerin çözümüne ilişkin öneriler: Arkadaş edinme sorunu, alay edilme, anksiyete-endişeler ve aşırı mükemmeliyetçilik üzerine bir çalışma. In 2nd International Conference on New Trends in Education and Their Implications (pp. 27-29).

Gürdoğan-Bayır, Ö. \& Gültekin, M. (2016). İlkokul dördüncü sınıf sosyal bilgiler dersinde çatışma çözme becerilerinin gelişiminin incelenmesi. Trakya Üniversitesi Ĕgitim Fakültesi Dergisi, 7(1), 86-103.

Halstead, J. M. \& Taylor, M. J. (2000). Learning and teaching about values: a review of recent research. Cambridge Journal of Education, (30),169-202.

Kabapınar, Y. \& Baysal, Z. N. (2004). İlköğretim hayat bilgis ve sosyal bilgiler öğretimine yaşamın kendisini taşımak: gazete haberinin kullanıldığı bir öğretimin tasarlanması ve değerlendirilmesi. Kuram ve Uygulamada Eğitim Yönetimi, 39(39), 384-419.

Kabapınar, Y. (2004). Illköğretimdeki hayat bilgisi ve sosyal bilgiler derslerinde kullanılacak bir öğretim etkinliği olarak resim çizimi yoluyla empati. Atatürk Ĕgitim Fakültesi Eğitim Bilimleri Dergisi, 20, 85-100.

Kanatlı Öztürk, F. (2018). Çokkültürlü eğitim çerçevesinde hazırlanan etkinliklerle farklılıklara sayg d değeri ve araştırma becerisi geliştirmeye yönelik bir eylem araştırması (Unpublished PhD Dissertation). Çukurova Üniversitesi: Adana.

Kepenekçi, Y. K. (2004). Sınıf öğretmenlerine göre hoşgörü. Kuram ve Uygulamada Eğitim Yönetimi Dergisi, 10(2), 250-265.

MoNE. (2018). Sosyal bilgiler dersi öğretim programı. Ankara. Accessed from http://mufredat.meb.gov.tr/Dosyalar/201812103847686-SOSYAL\%20B\%C4\%BOLG\%C4\%BOLER\%20\%C3\%96\%C4\%9ERET\%C4\%BOM\%20PROGRAMI\%20.pdf on 20.12.2018

Meriç, A. \& Özyürek, A. (2018). Okulöncesi dönem çocukların ahkali ve sosyal kural bilgilerinin incelenmesi. Ulus/ararası Toplum Araştırmaları Dergisi, 8(14), 137-166.

Merriam, S. B. (2002). Qualitative research in practice: examples for discussion and analysis. San Francisco: Jossey-Bass.

Olson, B. (2003). Attitudes toward multiculturalism and cultural diversity: the effects of multicultural training (Unpublished Master Thesis). University of Wisconsin.

Öksüz, Y. \& Güven, E. (2012). Farklılıklara saygı ölçeği (fsö): geçerlik ve güvenirlik çalışması. The Journal of Academic Social Science Studies, 5(5), 457-473.

Öksüz, Y., Güven, E., Baba, M., \& Kartal, A. (2015). Investigating primary school students' perceptions about differences through their drawings. International Periodical For The Languages, Literature and History of Turkish or Turkic, 10(3), 529-544.

Schwartz, S. H. (1994). Are there universal aspects in the structure and contents of human values?. Journal of Social Issue, 50(4), 19-45.
Senemoğlu, N. (2012). Gelișim, öğrenme ve öğretim kuramdan uygulamaya. 21. Baskı. Ankara Pegem Akademi.

Söylemez, B. (2017). Üniversite öğrencilerinin ahlaki yargı düzeylerinin dempgrafik değişkenlere göre incelenmesi (Unpublished MA Thesis). Mersin: Çağ Üniversitesi.

Sözer-Çapan, A. (2005). 3-11 yaş çocuklarının ahlaki gelişimlerinin Piaget'in ahlaki gelişim kuramına göre incelenmesi (Unpublished MA Thesis). İstanbul: Marmara Üniversitesi.

Topaloğlu, B. (2014). Alay edilme algısı ölçeği ergenler için geçerlilik ve güvenirlik çalışması: beden imajı ve kontrol kaybı ile ilişkisi (Unpublished MA Thesis). İstanbul: Okan Üniversitesi.

Topçubaşı, T. (2015). Farklııklara saygı eğitim programının öğrencilerin farklılıklara saygı düzeyine etkisi (Unpublished MA Thesis). Kocaeli Üniversitesi: Kocaeli.

Ulusoy, K. (2017). Hayat bilgisi dersinde değerler ve değerler eğitimi. B. Tay (Ed). In Etkinlik örnekleri ile hayat bilgisi öğretimi (pp.323-350). Ankara: Pegem Akademi.

Uymaz, M., \& Çalışkan, H. (2018). Determination of perceptions of social studies teacher candidates about empathy by means of metaphors. Journal of Multidisciplinary Studies in Education, 2(4), 80-91.

Weisman, E. M. \& Garza, S. A. (2002). Preservice teacher attitudes toward diversity: Can one class make a difference?, Equity and Excellence in Education, 35(1) 28-34.

Witenberg, R.T. (2007). The moral dimension of children's and adolescents' conceptualization of tolerance to human diversity. Journal of Moral Education, 36(4), 433-451.

Yeşil, R., \& Aydın, D. (2007). Demokratik değerlerin eğitiminde yöntem ve zamanlama. Türkiye Sosyal Araştırmalar Dergisi, 11(2), 65-84.

Yıldırım, A. \& Șimșek, H. (2013). Sosyal bilimlerde nitel arastırma yöntemleri. İstanbul: Seçkin Yayıncılık.

Yılmaz, S. (2016). Milenyum çağının unutulan gerçeği: şahsiyet ve değerler eğitimi. Ankara: Vize Yayıncılık. 